\title{
TURKEY AND JAPAN: GENERAL OUTLOOK OF EDUCATION SYSTEMS AND TEACHER EDUCATION
}

\author{
Hasan ŞEKER \\ Department of Curriculum and Instruction, Education Faculty, \\ Muğla Sitkı Koçman University, Turkey \\ E-mail: hseker@mu.edu.tr \\ Kenji MAEHARA \\ Curriculum Center for Teachers, Tokyo Gakugei University, \\ Tokyo, Japan \\ E-mail: maehara@u-gakugei.ac.jp
}

\begin{abstract}
This study investigates the overall process of current educational systems both in Turkey and Japan with a focus on teacher training process. This study has administered a descriptive method. In the comparison of the data of the two countries Bereday's "comparative research model" has been used. In the first place, the general characteristics of the two educational systems have been examined. In this section such topics which are related to compulsory education, schooling ratios, higher education, and vocational training have been tackled. In the following section the teacher training systems in both countries have been examined. It has focused on teachers' responsibilities and working times, pre-service teacher education in both countries, in service training, the selection and appointment of teachers, and through findings discussions have been conducted.
\end{abstract}

Key words: Japan, Turkey, education systems, teacher, teacher training

\section{TÜRKIYYE VE JAPONYA: EĞITIM VE ÖĞRETMEN YETISSTIRME SISTEMLERINE GENEL BİR BAKIŞ}

Özet:

Bu çalışmada Türkiye ve Japonya'daki eğitim sistemlerinin günümüzdeki genel görünümü ve öğretmen eğitimi süreci incelenmiştir. İki ülke eğitim verileri Bereday'ın karşslaş̧tırmalı araştırmalar modeli ile kullanılmıştır. İncelemede her iki eğitim sisteminin genel özellikleri değerlendirilmiştir. Çalışmada öncelikle zorunlu eğitim ve okullaşma oranlarl, yüksek ögretim ve mesleki eğitim konularına değinilmiștir. Makalenin daha sonraki bölümünde ise özel olarak her iki ülkenin öğretmen yetiştirme sistemleri ele alınmıştır. Bu kapsamda ögretmen sorumlulukları, onların çalışma zamanları ile ögretmen yetiş̧tirme süreçleri değerlendirilmiştir. Ayrica hizmet öncesi- hizmet içi yetiştirme süreçleri incelenerek öğretmenlerin seçimi ve atamalarına iliş̧kin bulgular yorumlanarak tartışılmıştır.

Anahtar kelimeler: Japonya, Türkiye, eğitim sistemleri, öğretmen yetişstirme 
The current general outlook of the Turkish and Japanese education systems are briefly summarized in the first part of the study under the headings of compulsory education and schooling ratios, tertiary and vocational education. In the second part of the study, the focus is on teacher education system such as teaching profession ( responsibilities of teachers and their working times, teacher-student ratio, teaching profession and gender, teacher selection and appointment, current state of teacher training in Japan and Turkey, in-service training in Japan and Turkey.

\section{Method}

This study, which investigates current outlooks of both Turkish and Japanese educational systems and the overall process of teacher training, has administered a descriptive method. It has mostly used Bereday's (Bray, 2005, Munzon, 2007) “comparative research model”. The study firstly describes pedagogical data from both countries and assessment of these data. Furthermore, comparisons have been made in line with the afore mentioned subheadings. In the final section of the study, the views of both authors have been compared and contrasted simultaneously and conclusions have been tried to be drawn.

\section{General outlook in Japan and Turkey: Schooling in Turkey and Japan \\ Compulsory education and schooling ratios}

In both Turkey and Japan, elementary education is compulsory and free. In Japanese constitution, it is stated that "All people shall have the right to receive an equal education correspondent to their ability, as provided by law. All people shall be obligated to have; all boys and girls under their protection receive ordinary education as provided by law. Such compulsory education shall be free." (Article 26). And this article secures the provision of compulsory and equal education. In Turkish constitution, it says "Nobody can be deprived of the right of education and instruction.... Elementary education is compulsory for everyone either being male or female and state schools are free (Article 42). As elementary education is free in both countries, almost all children are attend elementary schools in both countries. In both Turkey and Japan, compulsory and free education is provided by law. In the Constitution of Japan, it says [...] (Article 26). This article secures the provision of compulsory and equal education for all, and Basic Act on Education provides "nine-year general education" as compulsory up to present. It is important here to pay attention that there is no obligation to go to school for children in Japan, but protector (mostly parent) is obligated to send them to school. Local Governments are obligated to set up enough amount of schools and defray costs. From the World War II, the Japanese compulsory education has consisted of 6 year primary school and 3 year lower secondary school. Compulsory education in Japan typically starts from 6 years and ends at the age of 15 years old. The ratio of attendance is $99.99 \%$, i.e. the compulsory education in Japan is completed quantitatively. After the lower secondary school, about $98 \%$ of students go to upper secondary school, including about $3 \%$ of part-time schooling. $57 \%$ of 18 years old students take tertiary education at university, and the ratio reaches to $73 \%$, if part-time students and vocational college students are also included (2012, MEXT).

It is seen the students aged 6-15 are subject to free and compulsory education in Japan. In Turkey, on the other hand, the education system consists of four-year compulsory elementary education and fouryear compulsory secondary education. Compulsory education in secondary schools was initiated in 2012. Before that, elementary education had been designed as 5 years plus 3 years (5 years for elementary education and 3 years for secondary education). As of the year 2012, the system has been 
rearranged as $4+4+4$. Until 1997 , the education system was arranged as $5+3+3$ and only first 5 of this (elementary school) was compulsory.

There are not any prerequisites for enrolling in elementary and secondary education in Turkey and Japan. When the situation is examined in relation to compulsory education, it is seen that there was 8year compulsory education in Turkey as of 1997. In Japan, high efficiency was obtained from the compulsory education (Maehara, 2014) and as a result of this; it was among the ten most successful countries in the fields of reading, mathematics and science according to the results of PISA exams in 2009. On the other hand, the scores of Turkey were found to be below the OECD mean scores taken from 2009 PISA exams (PISA, 2009). According to 2012 data, the ratio of elementary schooling in Turkey is $98.67 \%$ and the ratio of secondary schooling is $67.37 \%$ (MEB, 2013). This shows that Turkey is far behind Japan in terms of schooling ratios. The ratio of 3-year high schooling in Japan is 98\% and the last level of secondary education in Japan is highly successful (Maehara, 2014). On the basis of the Japanese success lie the educational applications performed in 1970s. For instance, Japan had much better applications than many developed countries in 1970. From mid-1970s to early 1980s, Japan was in a better position in terms of mathematics and reading achievement (at elementary level) than other countries. This shows that teacher education and teaching culture had important contributions to these successful outcomes. Some reasons for the Japanese success are pointed out as: the cultural effect of traditional Confucianism from a cultural historical viewpoint, the open possibility of social success according to their school attainments from a sociological viewpoint and the high performance of teachers who were trained in universities, which will be illustrated further in the second part of this study.

In Japan, the students graduating from high schools have to take a national entrance examination to have a place at a university. Those taking high grades from this exam can attend prestigious schools. In addition to this general exam, teacher training institutions or institutes may want the candidates to take their own exams (Wang, Coleman, Coley \& Phelps, 2003). In 2011, 53.9\% of the high school graduates were able to start higher education in Japan (Maehara, 2014). There is a similar university entrance exam in Turkey. Students are placed at universities according to the results of this exam; no extra exam can be administered by universities or faculties themselves. Departments of fine arts and sports and physical education etc., are exceptions to this. Students wanting to attend these schools may have to take some extra exams.

Today, more than $80 \%$ of Japanese higher education is run by private organizations. The support provided by the state only accounts for $10 \%$. The competition among Japanese universities is fiercer than that of Turkish universities. In Japan business organizations and universities and institutes started to work as research partners. This cooperation which changes depending on universities may lead to differences among universities. This affects students' university selection. University is considered to be the first step for a secure job. Therefore, university entrance examination is like a hell for Japanese students (Goodman, 2010, p. 74). In Japan, the students who want to have a place in a university have to have an entrance examination which is organized by each university or each faculty. Concerning national universities, there are the National Center Examination as the first one and the local examination as the second one. After the local examination, which each student take at the one institution they want to attend, each university decides a list of accepted students by adding up the individual score of two examinations, giving some weights originally on it often.

Private universities play a great role in the construction of Japanese higher education. $80 \%$ of students belong to the private sector, which needs twice or three times higher fees than national universities. Private universities (or facilities) organize their own entrance examination each. Pupils entry voluntarily to many universities including national ones, and choose the most prestigious ones to

Muğla Eğitim Fakültesi Dergisi, Cilt / Volume 1. Sayı / Number 1. Mayıs / May 2014 
attend. All that means, that the successful graduation from the upper secondary school gives students a fundamental qualification to apply the entrance emanation, but no guarantee for admission.

This Japanese entrance examination system with the hierarchical ranking of prestige of universities has a merit on one hand that it encourages pupils to study hard in order to get a good score, but a demerit on the other hand that most students can't help having an inferior complex for failing to go to more prestigious universities. Some argue the burn-out of students after the entrance; others discuss the risk of the Japanese higher education which seems not to have good competences against the globalization of higher education.

The bad effect of this exam-oriented education is observed not only in tertiary education, but also in secondary education. According to the PISA 2012 report, the percentage of Japanese pupils as to "drive and motivation" for mathematics is almost ranked at the lowest group for all related subjects. For example, the percentage of students who agreed with the statement "I am interested in the things I learn in mathematics" is $53.1 \%$ of OECD average, $62.1 \%$ of Turkey and $37.8 \%$ of Japan. It becomes therefore a theme for educational policy in Japan to rebuild a spontaneous interest and motivation for study.

The enrolment ratio of 4 year old pre-schoolers is about $90 \%$ in Japan (OECD, 2013) this ratio is just about $44 \%$ in Turkey according to 2012-13 statistics issued by the Ministry of National Education. As to pre-school, the enrollment ratio of 4 year old pre-schoolers is about 90\% (OECD, 2013). It is estimated that about 55\% attend kindergarten; about $35 \%$ attend nursery schools which are organized as a welfare institution mainly for working mother (MEXT, 2013).

\section{Tertiary and vocational education:}

According to OECD data (OECD, 2013), when compared to OECD countries, it is seen that the participation of the young population in Turkey (population aged 15-25) in employment and education is quite low. While the percentage of young population not involved in labor force and education is $35 \%$, it is $16 \%$ on average for OECD countries. Males compared to females are more disadvantageous. On the other hand, in Turkey almost all children aged 5-14 (95\%) were enrolled in an educational institution in 2011. The schooling ratio among the adolescents aged 15-19 has increased more than twice in the last decade and reached $64 \%$. In OECD countries, the same ratio is $84 \%$. The current state of the compulsory education is hoped to improve this rate. According to OECD data (2013, a quarter of the adolescents having a degree work in part-time jobs. Out of the adolescents without a degree, only two fifths can work in part time jobs. In OECD report (2013), it is emphasized that though Japan has a successful education system and economy, there is a need for some adjustments in the education system to meet the changing demands of labor market and rapidly changing demographic profile.

When the per-student annual average expenditure is examined, Japan is a bit above the OECD average; yet, Turkey holds the last place. The public expenditure on educational institutions is ranked at the least group in OECD countries with $3.7 \%$. In the level of primary, secondary education, the ratio is not so low, but it is about one-fourth of the OECD average in the pre-primary education, about a half in the tertiary level. The role of private expenditure in these two sectors is much greater, which is a remarkable feature of educational funding in Japan (OECD 2013, Chart B2.3).

\section{Teaching profession}

Responsibilities of teachers and their working times: 
It is seen that the secondary school teachers in Japan work 1883 hours per year. According to the 2011 OECD data, Japanese teachers are among teachers with the highest working time. Besides classroom time, Japanese teachers also spend some time with students in extracurricular activities by providing guidance and they are also involved in administrative duties (OECD, 2013). At almost every level of schooling, teaching students in class is only a part of the professional responsibilities. They also assume some other duties and roles such as overseeing a club, performing some activities in the teachers' room and carrying out some administrative activities (Kumazawa, 2013). All these show that Japanese teachers have a heavy work load. It may sound paradoxical; however, this diversity of teachers' responsibilities constructs attraction of teaching profession in Japan. According to a recent survey, over 90 percent of teachers affirms as charm of teaching profession "to be able to share all feelings with students" and "to be able to develop oneself with students", but only 28 percent affirms "comfortable working condition" (Benesse, 2010).

In Turkey, teachers working in state schools spend most of their time on the cognitive development of students. They also spend some time voluntarily after classes and on their students' academic development in return for some payment. According to Kumazawa (2013), Japanese teachers target their students' emotional, physical, social and cognitive development. According to OECD reports the number of teaching days is about 200 days in Japan, 180 days in Turkey and 185-193 in OECD on average. The statutory working time in hours per year reaches upto 1883 hours for Japanese primary school teachers, 1816 for Turkey and 1671 for OECD on average. It is to be noted here that teachers in Japan work in fact much more. They work 2 hours overtime per day on average (i.e. about 400 hours in a year) as stated by the official survey of teachers' working condition by the Ministry of Education. Moreover, teachers of public schools in Japan can't receive any overpay in proportion to their work, for return of an across the broad allowance of 4 percent. While teachers in Turkey spent 639 hours in teaching in elementary education and 567 hours in upper secondary education, teachers in Japan spend 731 and 510 hours respectively. The gap between elementary and secondary education in Japan is explained by the fact that elementary teachers in Japan are in charge of all subjects as classroom teachers.

In Japan there are three semester vacations in elementary and secondary schools. The longest of this is four-week summer holiday. One of the other two vacations is in winter and the other one is in spring. In Turkey, there are two semester holidays. One of them is a long summer holiday (two and half months for students and nearly two months for teachers. Teachers start their holiday two weeks after students and in this two weeks' time, they participate in some seminars). And the other one is twoweek winter holiday. In Japan, elementary and secondary school programs are under the control of the Ministry of Education Culture Sports Science and Technology (MEXT) to ensure standardization in education (Kumazawa, 2013, pp.47). In a similar manner, the education is under the control of a central authority in Turkey. In Japan there are three semester vacations in elementary and secondary schools. The longest is six-week summer holiday. Teachers in Japan have a duty to go to work to their school, or take part in in-service training. If teachers want to have holidays during school vacations, they use paid holidays which they can take up to 20 days per year the same as other civil servants. During school vacations, most schools, especially lower secondary schools, provide a big amount of extracurricular activities of sports and culture for students, which are also conducted by teachers. These extracurricular activities are organized after school throughout the year in lower secondary schools.

In Japan, the elementary and secondary school curricula are drawn up by individual schools, based on the Course of Study which is edited by the Ministry of Education, Culture, Sports, Science and Technology (MEXT), in accordance with and specific circumstances of school and students. The text books used in schools are censored by the council in the MEXT. 


\section{Teacher-student ratio}

In Japan, teachers have more students when compared to the other OECD countries. On average, there are 28 students in an elementary school class, and there are 33 students in a secondary school class in Japan. These figures show that it has the second highest ratios among OECD countries. Average number of students in a class in OECD countries is 14. Compared to Japan, these numbers are a bit lower in Turkey. According to 2012-2013 National Education statistics, on average, there are 24 students in an elementary school class in Turkey. The PISA study organized by OECD shows that there is no clear evidence for correlation between the class size and the attainment of students who study there.

\section{Teaching profession and gender:}

Chart 1. Percentage of females among teaching staff in public and private institutions, by level of education

\begin{tabular}{lllll}
\hline & $\begin{array}{l}\text { Pre-primary } \\
\text { education }\end{array}$ & $\begin{array}{l}\text { Primary } \\
\text { education }\end{array}$ & $\begin{array}{l}\text { Lower } \\
\text { secondary } \\
\text { education }\end{array}$ & $\begin{array}{l}\text { Upper } \\
\text { secondary } \\
\text { education }\end{array}$ \\
\hline OECD average & 96.5 & 82.1 & 67.5 & 56.5 \\
Turkey & 92.9 & 52.9 & - & 42.5 \\
Japan & 97.0 & 65.0 & 41.7 & 28.4 \\
\hline
\end{tabular}

Source: Education at a Glance 2013, OECD 2013. Chart D5.2. Gender distribution of teachers (2011)

In Japan, the percentage of females among teaching staff is lower than the OECD average in all educational institution, except for the pre-primary education. (D5.2) In consideration of this femalization of teachers, it can be said that there is a big amount of room for females to find a position in Japanese schools.

From the data issued by the Ministry of National Education in Turkey, the distribution of male and female teachers in 2012-2013 school years is as follows:

Chart 2. The distribution of male and female teachers in 2012-2013 school years in Turkey

\begin{tabular}{llll}
\hline $\begin{array}{l}\text { Type of school } \\
\text { (2012-2013 Educational year) }\end{array}$ & $\begin{array}{l}\text { Females } \\
\text { teachers } \\
(\mathrm{n})\end{array}$ & $\begin{array}{l}\text { Male } \\
\text { teachers } \\
(\mathrm{n})\end{array}$ & $\begin{array}{l}\% \text { female } \\
\text { ratio }\end{array}$ \\
& & & \\
\hline Primary school (public) & 163.106 & 118.937 & 57.85 \\
Primary school (private) & 15.385 & 5.161 & 74.88 \\
Junior high school(public) & 140.403 & 129.356 & 52.05 \\
Junior high school (private) & 11.922 & 7.004 & 62.99 \\
Secondary education (public) & 112.996 & 141.899 & 44.33 \\
\hline
\end{tabular}

From the data presented in the table above, it is seen that teachers in Turkey are recruited mostly in state schools. When the table is examined, it becomes evident that the number of female teachers in both elementary and secondary schools is higher than that of male teachers. But this change in the higher levels of education is in favor of males. In private sectors, female teachers are preferred more in both elementary schools and secondary schools.

\section{Teacher selection and appointment:}


People who want to become a teacher of public maintained schools must pass the teacher selection examination. Due to the open system of teachers' degrees, graduates with teaching degrees have been always been much more than the amount of wanted teachers except for a period of time after the World War II. The opening-to-application rate of teachers is 5.7 for elementary school and 15.2 for secondary school (summed up all subjects) in Tokyo 2012 (Tokyo metropolitan board of education, 2013). These high competitive rates are explained by high reputation of teaching profession in Japan on the one hand, and by the continuous drop of birthrates which decrease teaching posts on the other hand.

Teacher selection examination consists of a paper exam (often multiple choice), essay writing, practical skills (teaching presentation) and interview. After an applicant passes the examination, s/he is appointed to a school in the prefecture or the ordinance-designated city. Mostly the candidate is asked an area where s/he wants to be allocated, but no one has no right to insist on the hope with regard to the school where s/he will be appointed. This is one of major features of educational administration of Japan.

Novice teachers work at a school for three or five years, then move to another school. Afterwards all teachers of public maintained schools change their workplace every 6 or 10 years, according to the personnel policy of the prefectural board of education: from a big school to a small one, from urban area to rural district, from a school with good socioeconomic background to a school with poor background and vice versa. This system is considered as a key factor to secure the equality of educational chance all over the country and an effective way to develop teachers' competences.

In both Japan and Turkey, teacher appointment is highly competitive. In Japan, in order to be able to be appointed as a teacher, pre-service teachers should take pen and pencil exams and then those passing these exams can enter a performance-based second exam.

In Turkey, there are two institutions training teachers. One of them is education faculties. The students having a diploma from an education faculty can work as a teacher in any part of the country if they pass the general teacher appointment exam. Each year certain numbers of teachers from different branches are appointed by the Ministry of National Education. In addition to this, graduates of the faculties of science and letters can be appointed as teachers if they complete a teacher formation program. This teacher formation education is given through courses organized by education faculties to a certain number of graduates of faculties of science and letters.

In order for pre-service teachers to be appointed as teachers in Turkey, they need to take Public Personnel Selection Exam (KPSS) after graduation. When the exams taken by pre-service teachers within KPSS are examined, it is seen that there are different areas such as general teaching methods, assessment and evaluation, education psychology, classroom management tested through multiplechoice questions. However, in 2013, in addition to these areas, subject areas exam was also added (English, Chemistry etc.). In Japan, it is seen that there are different selection methods for teachers' appointment. There are some written exams to test pre-service teachers' attitudes and skills; there are some application works such as physical exercises, drawings, foreign language performance, interviews, essay/thesis examination, micro teaching, classroom activities, lesson plan designing, role plays and simulations used in the selection of teachers in Japan. In Japan, pre-service teachers have to take written and spoken exams and have interviews to be able to become teachers. The written test includes education theories and methods, educational psychology, counseling and guidance, subject area knowledge and regulations and laws of education, educational administration and general school culture. In the interviews, pre-service teachers are requested to perform some dramatization related to a lesson. Pre-service teachers have a one year period of probationary (Fujita \& Dawson, 2007). In 
Turkish education system, there is a period of internship but the appointment of teachers in Turkey is made through a central exam made up of multiple-choice items. In 2013-2014, some subject area questions were included in the central exam.

In Turkey, 252741 pre-service teachers took the exam of educational science in 2013. And in the same year, the number of teachers to be appointed by the Ministry of National Education was announced to be 40000 . This means that only $15.8 \%$ of the pre-service teachers can find a teaching position in state schools (this ratio may change from a teaching branch to another). In both Turkey and Japan, the newly appointed teachers do not have the freedom of changing the school they wish to work at. Teachers are appointed to vacant posts.

Though there have been some improvements in the economic conditions of teachers in Turkey in recent years, the average wage of elementary school teachers is quite lower than OECD average (OECD,2013). The wages of the teachers in Turkey are much lower than OECD on average. In countries, the experience, performance and quality of teachers do not affect their wages much. Though there is a difference between the wages of teachers in Japan and those of the teachers in Turkey, it is remarkable that there has been a relative decrease in the wages of Japanese teachers and relative increase in the wages of the teachers in Turkey in the last decade. The salary of Japanese teachers in US Dollars is a bit lower than OECD average in both primary and lower secondary education in 2011. (Table B7.1) This reflects the salary reducing policy for public officials including teachers throughout this decade, which has brought almost a $10 \%$ decrease of the average salary of teachers. Some argue that this might lead to a decline in teacher's aspiration and performance. Focusing on the salary in percentage of GDP per capita, there is no clear difference between Turkey with 8.1 and Japan with 8.3 in primary education.

\section{Some thoughts about teacher education systems in Japan and Turkey Short history of teacher education in both countries}

Both Japan and Turkey have a long history of education. In Japan, construction of public education started after the Meiji Restoration in 1868 which brought the era of the feudal Japanese military aristocracy called samurai to an end. The Meiji government introduced the modern educational system after western countries. In Meiji era (1868-1912), the school system had developed all over Japan, partly due to the tradition of terakoya* which was already popular before the Meiji Restoration as a non-formal basic educational institution for the common people. (Ministry of Education, 1980). The high rate of developed literacy in Japan made great contributions to the economic development and national defense of the country against western powerful countries (Shimizutani, 2011, p.105). In 1905, the ratio of the young people graduated from elementary school was 90\% (Goodman, 2010, p.60).

Interestingly, the Meiji government organized a Normal School for teacher education a little earlier than the proclamation of the first modern school law. This first Normal School in Tokyo was also an introductory institution of western teaching methods at the same time. Thereafter, a lot of normal schools were built in each prefecture. The graduates of the Normal School in Tokyo were mostly sent to those prefectural normal schools and played a great role as a teacher of teachers. The normal schools, which received students from 14 to 19 years old and located as a secondary level in the educational system in prewar Japan, was the most standard way to become an elementary school

* Terakoya is originally a small place attached to a temple in which a priest teaches pupils reading and writing. "Tera-ko-ya" means temple, pupil and house.

Muğla Eğitim Fakültesi Dergisi, Cilt / Volume 1. Sayı / Number 1. Mayıs / May 2014 
teacher. They, however, couldn't cover the increasing demand for teaching staff, so teachers without formal qualifications were not unusual throughout the entire prewar era. Meanwhile, the Normal School in Tokyo had developed to the Higher Normal School, which aimed to train teachers of secondary schools, including prefectural normal schools.

After the World War II, the educational system in Japan was totally reformed under the strong influence of GHQ of the United States of America. Concerning teacher training, two fundamental principles were adopted: teacher training at university and open system for teachers' license. The former means that all teacher training should be given neither at secondary school nor vocational college, but at university as an academic institution. The latter means that all university which fulfill national standards for teacher training can open the way to get teachers' license, even if it is not established as a teacher training institution. Normal schools were reorganized as university or a faculty of university, accordingly. It is said that this reform has made Japan the first country which has introduced teacher training at university as a statutory standard (Sato, 2013). Nowadays there are universities and faculties only for teacher training, whose origins were mostly normal schools in prewar era, but they have no privilege concerning giving teacher licenses. They also have to get accreditation from the Ministry of Education just the same as other universities and faculties.

The open system for teachers' license was not adopted for the sake of overcoming the problem of shortage of teachers, and because the requirements for teacher license of secondary schools are quantitatively small, it is easy for most universities and faculties to organize certificate programs additionally during four year schooling. In Contrast, the requirements for elementary school teacher are so full; resulting from the classroom teacher system mentioned before, that the certificate program for elementary school teachers cannot be organized additionally. Totally, more than 500 universities give students some teacher training certificates programs (Iwata, 2004).

In the period which may be called Atatürk's era in Turkey, the main purpose of education was to raise public awareness through village education and to generate new generations to protect the existence of the Republic. The founder of the Republic, Atatürk, set the vision of the teachers by saying "Teachers, you will educate the new generations of the Republic". There are many important sayings of Atatürk in this respect. Grounds of many education institutions were laid in this period. Moreover, in 1928, the Latin alphabet took the place of the Arabic alphabet.

In the first years of the Republic, people were mostly living in the countryside and villages; hence, the number of literate people and teachers was small. The turning points of teacher education in Turkey were in the era of Atatürk and subsequent multi-party period (after 1946) and 1982 when the teacher education was put under the responsibility of universities in Turkey.

In the first years of the Republic of Turkey, great strides were made in both development and education. In 1924, all the science and education institutions were put under the roof of the Ministry of National Education. In this way, educational and instructive activities were under the control of one authority. Moslem theological schools were closed and important steps were taken for the secularization of the system. In the Republic era, all the students were given democratic and republican education (Akyüz, 1985, p.308). In the first years of the Republic, there were teachers only in 4000 villages out of 45000 ; that is, there were teachers only in one out of ten villages. Moreover, out of all elementary school teachers, 30-35\% were graduates of teacher education schools (Y1ldiz, 2004, p. 302). In this period, as stated by Atatürk, the army had "won the war" but teachers had to win the war for civilization. As high majority of the population lived in villages $(80 \%)$, rate of literacy was low and the teachers had to take important roles in the introduction of the Republic to the people. In this period, faster ways of training teachers were sought. In the first years of the Republic,

Muğla Eğitim Fakültesi Dergisi, Cilt / Volume 1. Sayı / Number 1. Mayıs / May 2014 
educators such as J. Dewey and Kühne were invited to Turkey and in his report, J. Dewey, emphasized the importance of village education. As a result of this report, Village Teacher Education schools were opened in Turkey between 1927 and 1936 (Akyüz, 1985, pp. 360). In these schools, education started three years after elementary education; yet, these schools were later closed on the ground that the quality of the teachers educated here was not good. After 1940, Village institutes were established.

These 21 village institutes opened far away from the cities used to give five-year education after elementary school. In the curriculum of these institutes, there were social sciences, painting, music, physical education, foreign language, teaching information courses. Moreover, agriculture courses and some technical courses were given in these institutes. The graduates of Village institutes generated new production methods, new markets for new products and they also assumed the responsibility of the works of schools and courses they worked (Akyüz, 1895, pp. 364). These institutes were criticized by people from both right-wing and left-wing as they mostly educated people with leftist ideologies, adopted coeducation, obligatory service of the teachers was very long, and prospective teachers were exploited. With the shift from technical and vocational education towards general education at these institutions, the functionality of these schools decreased. These schools were combined with first teacher education schools and closed in 1954.

The period when the political instabilities were experienced and quantity became more important than quality is the multi-party period after 1946. Turkish miltary did not take part in World War II , yet, experienced some negative impacts of the war. With the law of National Protection passed in 1940, war economy was implemented in the country. In this period, what accelerated the orientation of Turkey towards West was the threat posed by the Soviet Union. Convergence towards West resulted in some democratic gains (Ulubey and Akçatepe, 2013, pp. 102). In the same period, after the declaration of United Nations stating that other parties apart from Turkish Republican Party (CHP) had to be established, it was announced that multi-party period would start (Karakök, 2011, pp. 90).

In 1950, elementary school teachers were trained in Urban Teacher Schools and Village Institutes. Until the amendment carried out in 1982, the need for teachers in secondary schools was met by threeyear education institutes. Between 1950 and 1960, the institute having active role in the education of teachers for high schools was High Teacher Schools. Up to mid-50s, the need for high school teachers was met by Istanbul High Teacher School. In 1959, another High Teacher School was opened in Ankara (Güven, 2010, cited in Karakök, 2011). General evaluation of these schools by Prof. Dr. Eşme, who graduated from them, is as follows:

With this new model, clever, talented, understanding, questioning and criticizing individuals selected from villages and towns were integrated into university environment. In the 1960s, some signs of deterioration were observed in this model. One of them was related to quantity. With the incommensurable increase in the number of High Teacher Schools led to the deterioration of student quality and selection. With the transformation of the first teacher schools into teacher high schools, the source of High Teacher Schools exhausted and the functionality of preparatory class got lost. Moreover, this would be proposed as the reason for the closure of these schools (Eşme, 2003).

These schools were closed in 1978. Between 1960 and 1980, the country was ruled mostly by coalition governments. A great number of governments came to the power and accordingly many ministers of education were in power during this period. In the Republic era, particularly in the period after 1960, various attempts were made to manipulate the teacher education system and they had negative impacts on the respectability of teaching profession. Some of these are:

In 1960, reserve officers were appointed as teachers (after a short training, during their military service, high school graduates were appointed as teachers to village schools), In 1970-1974, some 
teachers were trained through letters. In 1977-79, short training services were provided (sometimes three-month training) for those who could not complete their teacher training programs and then they were appointed as teachers (Özoğlu, 2010 pp. 6).

In Japan, $10 \%$ of the high school graduates took university education in 1960 s, $49.9 \%$ of the high school graduates took university education and this ratio reached $76.2 \%$ in 2005 and this is the highest in the world (Takeueki, 2007, cited in Goodman, 2010, p. 68).

\section{Current state of teacher training in Turkey}

In Turkey, teacher training was put under the responsibility of universities in 1982. With the Higher Education Law passed in 1981, all higher education institutions were connected to universities. These included teacher training institutions (two-year education institutes and 4-year High Teacher Schools) connected to the Ministry of National Education (Kavak, Aydın, and Altun, 2007, p. 37).

Higher Education Council (YÖK) decided to open "educational sciences departments" at education faculties on 12 October 1982 to offer teaching knowledge courses. In the following years, at universities not having education faculties, educational sciences departments were set up at faculties of science and letters. The institutions transformed from two-year Education Institutes into Education Colleges went on training "classroom teachers" within a two-year program until 1988/89 academic year. Two-year education time was increased to four-year education in 1989-90 academic year and education colleges became education faculties. Since then, university education has been a must to become a teacher at every level of schooling. In order to determine the weights of the courses such as general knowledge, pedagogic formation and subject area courses in the programs of education faculties, it was decided to work in cooperation with the Ministry of National Education (Kavak, Aydın, Altun, 2007). The pedagogic formation program proposed in 1982 is as follows:

Chart 3. Pedagogic Formation Program (19 November 1982)

\begin{tabular}{lcl}
\hline Course name & Weekly class hours & Term \\
\hline Introduction to education & 3 & I \\
Educational sociology & 3 & II \\
Educational Psychology & 3 & III \\
Principles and methods of education & 3 & IV \\
Assessment and evaluation & 3 & V \\
Educational technology & 3 & VI \\
Guidance & 3 & VII \\
Special teaching methods & 3 & VII \\
Educational administration & 3 & VIII \\
\hline Special teaching applications & 30 days & VIII \\
\hline
\end{tabular}

TOTAL 27 hours + application

Though the above-given program was implemented for a long time, its application varied from one faculty to another. Just three years after the amendments made in the pedagogic formation program, the Ministry of National Education informed Higher Education Council about a need of revising the teacher formation program. They wanted pedagogic formation courses to be between 18-21 credits and eight-week compulsory teaching practice to be implemented. As a result, the time of teaching practice was increased and stayed until 1989.

In the 1990s, there were many studies emphasizing the shortage and quality of teaching practices. Until 1990, the teaching practices were very few and sometimes they were limited to two-week periods. Shortage of teaching practices and the dominance of theoretical courses in teacher training 
were closely related to criticisms directed to Turkish education system as being based on memorization and theory.

The national education council gathered in 1982 required teachers to be trained with equal emphasis on fields such as general knowledge, subject area knowledge and professional formation. The aim was to train qualified teachers knowledgeable about theory and practice. Moreover, graduates of faculties of science and letters were granted right to become teachers if they completed a 26 -week program with 21 weekly class hours within a pedagogic formation course.

Both these courses and education and standardization in faculties were highly debated in 1990s. Sözer (1990) stated that content categories changed according to subject area. Moreover, there were differences in terms of time and quality of teaching practice courses among faculties. Gültekin (1993) found that the credits of teaching pedagogy courses taught in four universities of Ankara varied between 17 and 24 and their ratio among all the courses taught was not more than $16 \%$. And how much of this can be spared for teaching practice courses so that qualified teachers can be trained? Saylan (1992) reported that subject area knowledge was attached more importance than teaching pedagogy; hence, teachers had some difficulties in their practices.

In 1997, some important regulations were made in teacher training programs. As a result, it was decided that subject area teacher education program would be as follows (Kavak, Aydın, and Altun, 2007, p. 53).

Chart 4. The courses given in secondary education subject area teacher education master's program without thesis (1997)

\begin{tabular}{ll}
\hline COURSES & Theory- Practice - Credits \\
\hline I. Term & \\
\hline 1. Introduction to teaching profession & $3-0-3$ \\
2. Development and learning & $3-0-3$ \\
3. Planning and evaluation in teaching & $3-2-4$ \\
4. Special teaching methods I & $2-2-3$ \\
5. School practice I & $1-4-3$ \\
\hline II. Term \\
\hline 1. Teaching technologies and materials & $2-2-3$ \\
2. development & $2-2-3$ \\
3. Spassroom management & $2-2-3$ \\
4. School practice II & $1-4-3$ \\
5. Elective I & $3-0-3$ \\
\hline III. Term & \\
\hline 1. Subject-area course book evaluation & $2-2-3$ \\
2. Counseling & $3-0-3$ \\
3. Teaching practice & $2-6-5$ \\
4. Elective II & $3-0-3$ \\
General total & $\mathbf{3 2 - 2 6 - 4 5}$ \\
\hline
\end{tabular}

Source: www.yok.gov.tr/egitim/tezsizyl/tezsizyl.htm

In 1997 program, following disputes about teacher qualities, the need for revision was felt and in 2006-2007, teacher training programs were rearranged. Some of the new regulations are as follows (Kavak, Aydın ve Altun, 2007, p. 63): 
The weight of subject area teaching knowledge and general culture were set respectively as: area \%50$60, \% 25-30, \% 15-20$, Faculties were granted freedom to determine $25 \%$ of their courses. The number of general culture courses was increased (philosophy, effective communication, and science history courses were proposed to be integrated into the program so that students could enhance their intellectual skills; moreover, a community service course was made required in all the programs by decreasing the hours of practicum.

The courses to be given in pedagogic formation were decided in a meeting of Higher Education General Board in 2010 and these courses are as follows: (YÖK, 2013).

Chart 5. Pedagogic Formation Education Certificate Program Courses

\begin{tabular}{|c|c|c|c|}
\hline Courses & Theory & Practice & Credits \\
\hline Introduction to the science of education & 2 & 0 & 2 \\
\hline Development psychology & 2 & 0 & 2 \\
\hline $\begin{array}{l}\text { Learning teaching theories and } \\
\text { approaches }\end{array}$ & 2 & 0 & 2 \\
\hline Program development and teaching & 2 & 0 & 2 \\
\hline Classroom management & 2 & 0 & 2 \\
\hline Counseling & 2 & 0 & 2 \\
\hline Assessment and evaluation & 2 & 0 & 2 \\
\hline $\begin{array}{l}\text { Teaching technologies and materials } \\
\text { design }\end{array}$ & 2 & 0 & 2 \\
\hline Special education methods & 3 & 2 & 4 \\
\hline Teaching practice & 2 & 6 & 5 \\
\hline Total & 21 & 10 & 26 \\
\hline
\end{tabular}

After 2012, Higher Education Council abolished the acceptance of students into master's programs without thesis to train teachers for secondary education.

Pedagogic formation education certificate program courses are scattered across undergraduate programs of education faculties. For the graduates of faculties of science and letters to participate in pedagogic formation courses, they need to first take Academic Personnel Graduate Entrance Exam (ALES). The candidates desiring to participate in formation programs were selected according to their scores from ALES exam, graduation grade point average and interview of the given faculty. As off 2014, candidates will apply to Student Selection and Placement Center (ÖSYM) through the Internet. Students will be able to apply any of the programs in OSYM table. Selections will be made according to the score of ALES exam (60\%) and average graduation point (40\%).

\section{Current state of teacher training in Japan}

Under the open system of teacher license, the Ministry of Education in Japan had revised several times the legal statutes for teacher license. Each time the statues have been revised, it is needed for universities with certificate programs for teacher license to be accredited again in their newly organized curriculum. The universities and faculties only for teacher training which are mostly national maintained have to get this accreditation on their own responsibilities in accordance with the revised statues, too.

In Japan, in order to be able to get a first-class teaching certificate, students are required to hold a bachelor's degree with 124 or more credits in a four-year study term as a basic qualification. Following requirements also need to be met:

A) Subjects for Education: $\quad$ 41+ (for elementary school teachers) 
$31+$ (for lower secondary school teacher)

Courses given in education-related subjects include courses such as basic theories, teaching methods,

school administration, curriculum structure, teaching practice (2-4 weeks) and so on.

B) Subjects for school subjects: $\quad 8+$ (for elementary school teachers)

$20+$ (for lower secondary school teacher)

C) Elective subjects on group A subjects or group B subjects (set up by each university or faculty)

$10+$ (for elementary school teachers)

$8+$ (for secondary school teachers)

D) Nursing care experience: 7 days in schools for SEN or social welfare facilities (no credits)

E) Some special designated subjects: The Constitution of Japan, physical education, foreign language

communication and operation of IT equipment (each 2 credits) (Iwata, 2004).

Students who fulfill the requirements of legal statues can get a teacher license at graduation. The license is given under the name of prefectural educational boards, but valid all over the country.

As mentioned above, most licenses for secondary school teachers are obtained as an option on the certificate program of non-teachers' universities and faculties. There are a lot of arguments about qualification of such license holders, because they might study lots of subjects they teach, but may not have enough pedagogical knowledge and practical ability. In fact, however, not only teachers who got their license as an option are criticized, but also who have studied teacher training at universities and faculties are brought up for discussion, too. The common critical point is that whether a teacher should have enough qualifications for his/her job at the time of employment or not. People who think that a novice teacher should also be completely developed professionally, which claims to raise the legal statues of teacher license or introduce an intensive teacher training at master program, aiming mainly at the development of practical ability as teaching profession. This is the biggest issue concerning the teacher education system in Japan in recent years.

Besides, most universities and faculties, especially those only for teacher training, organize a variety of unique planning for teacher education, exceeding the requirements of the legal statutes. For instance, the Tokyo Gakugei University, ex-Normal School in Tokyo, provides students a series of "study on site" (Tokyo Gakugei University, 2010). In the second semester, students attend a one-day school visit, following some lectures by in-service teachers and principals of the school. For this, Tokyo Gakugei University does cooperation with four local school boards of education of neighboring cities. Students can take part in optionally three-day school visits in the third or fourth semester, accompanied with guidance and reflection for each day. Students of Tokyo Gakugei University go to teaching practice both at the attached schools for three weeks in the 5th semester and at public maintained schools for three weeks in the 7th semester, that is six weeks in all, twice as much as the legal requirement. Furthermore, the university secures more chances of teaching practice for students who want to get double licenses, for example license of elementary school and secondary school, or schools for SEN. On some conditions, voluntary work at schools can be the subject of credit.

Other universities organize their own inventive planning, too. Hirosaki University has introduced "Tuesday practice", which gives students chance to study on site throughout a year by sending them to the attached school every Tuesday (Fukushima et.al. 2013). Shimane university has required students to do "1000 hours practice" during four years, which consists of teaching practice as student teacher, school visits, voluntary work at school and experience of clinical counseling (Hata and Morimoto, 2005). Needless to say, it doesn't mean that most universities and faculties in general make such inventive programs in Japan, exploring better teacher training. It is not too much to say that they in general they barely fulfill the requirements of legal statues.

Incidentally, concerning the teaching practice on site, faculty staffs of universities are in charge with preparatory guidance and reflection after the practice. All training during practice term is organized,

Muğla Eğitim Fakültesi Dergisi, Cilt / Volume 1. Sayı / Number 1. Mayıs / May 2014 
conducted and evaluated by a teacher of the school where a student is assigned. University staff sometimes visits teaching practice on site, but does no coach at all in general.

Teachers who are given 1st class license after they graduate can get a Premier License, if they complete master programs. This Premier License, however, gives its holders no privilege in the process of selection and appointment, as it is described below.

When compared to other countries, it is seen that in Japan and Turkey, less time is spent on teaching practice. In Holland, the time spent on teaching practice is between 48 and 72 weeks and in England it is 24 weeks (Wang, Coleman, Coley \& Phelps, 2003). As a result of the discussions about the shortness of teaching practice time in Turkey, now, pre-service teachers go to schools where they do their teaching practicum for 28 weeks (at least four hours a week).

\section{In-service Training in Japan and Turkey:}

In Turkey, in-service training is given under the coordination of the directorates of national education with the support of universities close to the region as short-term seminars. According to in-service training code (Article 24), the people to deliver in-service training, activities to be performed, dates and teaching programs are determined by the Directorate of In-service Training with the approval of the Ministry of National Education and no amendment can be made without the permission of the Ministry of National Education. In Japan, in-service training is conducted by means of nationally administered programs and local programs (Fujita \& Dawson, 2007). In nationally administered programs, participants present what they have learned in their schools and close surroundings. In Japan, both short-term and long-term in-service training programs are conducted mostly by the prefectural center for education. For novice teachers, one-year initial training program is provided through legal statutes. This one year initial training program consists of two parts, in the first part, in campus training at the prefectural center for education is provided for 60 days (two days in a week) and in the second part, out-of-campus training is given for one day in a week. This program supervised by mentors includes courses, seminars, workshops, school visits and social activities (Fujita \& Dawson, 2007). The program for teachers with a 10 year experience consists of 12 days in campus training and 18 days on site training on average (Ministry of Education in Japan, 2014). In 2009, the periodic renewal of teaching licenses was introduced, which requires attending 30 hours in-service training at universities every 10 years. Through this, the program for teachers with 10 year experience is partly replaced with the renewal of teaching license. Outside of this obligatory in-service training, there are a lot of programs on site for subjects, teaching methods, understanding of students, class and school management and so on. Interactive lesson observation with colleagues ("Lesson Study") is also a popular style of in-service training (National association for the Study of Educational Method, 2011).

In addition to this, in-service training offering special courses related to issues such as bullying and truancy is also given (Bayrakc1, 2009). Lack of professional staff for planning and conducting inservice training activities in Turkish National Education System seems to be the main problem of such programs (Bayrakc1, 2009). In Japan, in-service training is given in a more organized way than in Turkey. In Turkey, Japanese in-service training experiences can be capitalized on. Though it is difficult, the profession of teaching is still popular among high school students in Japan (Fujita \& Dawson, 2007).

There are, however, some discussions regarding "in-service training tired" teachers in Japan. A background of those discussions is an intensification of teachers' work. Some insist on restructuring of in-service training in order to secure a better condition for work on site and professional development of teachers (Urano, 2011). 


\section{Discussion}

The main purpose of education in early years of the Republic was to train individuals comprehending the philosophy of the Republic and approving reform movements so that the Republic could be developed. Moreover, with the adaptation of the Latin Alphabet in 1928, other primary aims of the education were to increase the number of literate people and raise the awareness of the public. In this period, high majority of people were living in the countryside, low levels of literacy and shortage of teachers resulted in an emphasis on quantity rather than quality.

In the Republic era, various means of training qualified teachers was tried. Yet, these attempts were shaped primarily by political and societal preferences ( Aydın, Şahin , \& Topal, 2008). Particularly after 1946, political instability was experienced and quality was sacrificed in favor of quantity in teacher training. The main emphasis of teacher training programs was on the quantity rather than improving the system and creation of policies directed to the quality of the teacher. In this respect, many reformation attempts focused on which courses should be included in the program and the balance between theoretical and practical courses.

Program and training revisions were made in a hurry. Scientific processes of the curriculum development have been neglected. In these attempts, decisions made by central authorities such as the Higher Education Council (YÖK) and Council of Deans were more effective. Hence, less emphasis was laid on program evaluation and development.

In teacher training, one of the important events is assigning the responsibility of teacher training to universities. In this period, some important steps were taken to improve the efficiency of teacher training system through some projects (Subject-area teacher training projects - YÖK and World Bank project of developing the national education). Quest and disputs for training qualified teachers are still going on. For instance, despite the lack of academicians to work, many education faculties have been opened and student quota of education faculties was increased and these are some of these obstacles in front of quality teacher training (Bilir, 2011, p.242).

In Japan, there are two main components of teacher training, which are training through researchbased teaching strategies and cooperation among teachers. The philosophy of Japanese teacher training system is based on training for the job and teaching culture (Fujita \& Dawson, 2007). In our country, on the other hand, teacher training is based on school and teaching practice and hands learning (Yıldırım, 2011). In Turkey, faculty members and school mentors are expected to play more effective roles in training the of teachers during teaching practice.

Fujita \& Dawson (2007) state that Japanese education system has two important characteristics: Job training and single staff room. Single staff rooms have some contributions to the formation of a collective culture and arrangement of instruction. Japanese schools aim to educate students through a holistic approach. For this purpose, various rituals, events and extracurricular activities are organized at schools. In Turkey, rather than the needs of children, their performance is emphasized. Students have to take an exam that will affect the rest of their lives even when they are at secondary school. This discourages students' participation in extracurricular activities and forces them to focus on testcentered activities. 
In both of the systems, in-service training may gain more importance. And examination of the Japanese system may help to improve selection and in-service training of teachers in Turkey.

\section{Referances}

Akyüz, Y. (1985). Türk Ĕgitim Tarihi. Başlangıçtan 1985'e. Turkish History of Education. From begining to 1985. (in Turkish) Ankara Üniversitesi Eğitim Bilimleri Fakültesi Yayınları: 149: Ankara.

Aydın, R., Şahin, H \& Topal,T. (2008). Türkiye'de ilköğretime sınıf öğretmeni yetiştirmede nitelik arayışları. Searching for Quality in the Training of Primary School Teachers in Turkey. (in Turkish) TSA, 12(2), 119-142.

Bayrakc1, M. (2009). In-Service Teacher Raining in Japan and Turkey: a Comparative Analysis of Institutions and Practices, Australian Journal of Teacher Education, 34(1), 10-22.

Benesse Education Research and Development Institute (2010), The fifth basic survey for teaching (Elementary and lower secondary school), (in Japanese). Retrieved from http://berd.benesse.jp/berd/center/open/report/shidou_kihon5/sc_hon/index.html

Bilir, A. (2011). The historical evolution of teacher training and employment politics in Turkey, Ankara University, Journal of Faculty of Educational Sciences, 44(2), 223-246.

Bray, M. (2005). Methodology and Focus in Comparative Education. Retrieved from http://web.edu.hku.hk/staff/mbray/docs/Bray_Methodology_\&_Focus.pdf.

Eşme, İ. (2003). Öğretmen Yetiştirmede 130 Yıllık Bir Sürecin Öyküsü: Yüksek Öğretmen Okulları. The story of A teacher training 130-year-old Process:High Teacher School (in Turkish) Milli Eğitim Dergisi, Sayı 160, http://dhgm.meb.gov.tr/yayimlar/dergiler/Milli_Egitim_Dergisi/160/ esme.htm kaynağından 2.1.2014 tarihinde indirilmiştir.

Fujita,H \& Dawson,W.P. (2007). The qualifications of the teaching force in Japan, Ingersoll,R.M. (Eds). A Comparative Study of Teacher Preparation and Qualifications in Six Nations (CRPE pp.4155). http://www.cpre.org/sites/default/files/researchreport/823_sixnationsfinal.pdf

Fukushima,H. et al.,( 2013). How the teacher education program reform has affected graduating students. Bulletin of the Faculty of Education, Hirosaki University, Vol. 109, 2013, pp.73-81 (in Japanese)

Goodman, R. (2010) The rapid redrawing of boundaries in Japanese higher education, Japan Forum, 22:1-2, 65-87, DOI: 10.1080/09555803.2010.488944

Gültekin, M. (1993). Öğretmen adayları için uygulama modelleri. Practice models for prospective teachers (in Turkish) Eğitim Bilimleri Fakültesi Dergisi. 25(2), 821-832.

Güven, İ. (2010). Türk Eğitim Tarihi, History of Turkish Education (in Turkish). : Naturel Yayınlar1.

Hata, K. \& Morimoto, N. (2005). A Research on Effects of Teaching Experiences in Basic Experience Area in the Semester for Juniors. Center for Research on School Education and Counseling Attached to the Faculty of Education Departmental Bulletin, Vol. 4, 2005, pp.1-12. (in Japanese) 
Iwata,Y. (2004). Recent trends on teacher education reform in Japan. Retrieved from: http://www.ugakugei.ac.jp/ currict/about/iwata.info/20041023beijing.pdf

Kavak, Y., Aydın, A. \& Altun, S.A.(2007). Öğretmen yetiştirme ve eğitim fakülteleri (1982-2007) (öğretmenin üniversitede yetiştirilmesinin değerlendirilmesi). Teacher training and Educationala Faculties (1982-2007) (in Turkish.) Ankara: Yükseköğretim Kurulu Yayını 2007-5.

Kumazawa, M. (2013). Gaps too large: Four novice EFL teachers' self-concept and motivation. Teaching and Teacher Education, 33,45-55.

Maehara, K. (2014). A critical histtrographical analysis of Japan's educational policies from the end of the World War II to 2000s. Unpublished manuscript.

Karakök, T. (2011). Menderes Dönemi'nde (1950 - 1960) Türkiye'de Eğitim. (Education in Turkey in the Menderes Era (1950 - 1960). (in Turkish). Yüksekögretim ve Bilim Dergisi/Journal of Higher Education and Science, 1(2), Pages 89-97.

MEB (2013). Millî eğitim istatistikleri. Örgün Eğitim National Education Statistics Formal Education 2012- 2013. T.C. Millî Eğitim Bakanlığı strateji geliştirme başkanlığı. (Ministry of national education strategy development presidency)

Ministry of Education, Science and Culture in Japan (1980), Japan's modern educational system,

MEXT (2013). Ministry of Education, Science and Culture in Japan.

Ministry of Education, Science and Culture in Japan (2014). "Survey result on teacher training for teachers with 10 years experience (2012)"

http://www.mext.go.jp/component/a_menu/education/detail/_icsFiles/afieldfile/2014/03/24/1314654 _1.pdf (in Japanese).

Munzon, M. (2007). Comparing Places. Bray, M, Adamson, B. And Mason, M. (Eds). Comparative Education Research- Approach and Methods. Comparative Educational Research Centre (pp. 85-122). Hong, China: Springer.

National association for the Study of Educational Method, (2011). Lesson study in Japan, (in English) Keisuisha.

OECD (2013), Table D3.1. Teachers' statutory salaries at different points in their careers (2011), in Education at a Glance 2013, OECD Publishing. doi: 10.1787/eag-2013-table192-en

OECD (2013), Table D4.1 Organization of teachers' working time (2011) in Education at a Glance 2013, http://dx.doi.org/10.1787/888932851953

OECD (2013), Table D4.2 Number of teaching hours per year (2000 and 2005-11) in Education at a Glance 2013, http://dx.doi.org/10.1787/888932851972

OECD (2013), Table D2.1 Average class size, by type of institution and level of education (2011) in Education at a Glance 2013, http://dx.doi.org/10.1787/888932851592 
OECD (2013), Table D2.3 Ratio of students to teaching staff by type of institution (2011) in Education at a Glance 2013, http://dx.doi.org/10.1787/888932851630

OECD (2013), Table D3.4 Trends in teachers' salaries between 2000 and (2011), in Education at a Glance 2013, http://dx.doi.org/10.1787/888932851820

OECD (2013), Chart B2.3. Impact of the economic crisis on public expenditure on education. in Education at a Glance 2013,

OECD (2013), "Teachers' salaries", Education: Key Tables from OECD, No. 1. doi: 10.1787/teachsaltable-2013-1-en

Özoğlu, M. (2010). Türkiye'de ögrretmen yetiştirme sisteminin sorunlarl. the teacher-training system problems in Turkey (in Turkish). SETA Analiz. http://arsiv.setav.org/ups/dosya/20275.pdf 2.1.2014 tarihinde indirilmiştir.

PISA (2019). OECD, PISA 2009 Database. http://dx.doi.org/10.1787/888932343342.

Sato, M.(2013), How the Abe government changes education? (in Japanese) Iwanami.

Saylan, N.(1992). Öğretmen yetiştirme eğitim-öğretim planlarının geliştirilmesi. Teacher trainingDevelopment of education-instruction plans. (in Turkish) Uludağ Üniversitesi Ĕ̆itim Fakültesi Dergisi. 8(2), 43-50

Shimizutani,S. (2011) Education Reform in Japan: A Course for Lifelong Learning, Asia-Pacific Review, 18:2, 105-114.

Sözer, E. (1990). Öğretmen yetiştirmeye ilişkin genel kavram ve ölçütlerin üniversitelerimizdeki uygulamalara yansimalar1. General reflections on the concept and criteria to teacher training application of the universities (in Turkish). Anadolu Üniversitesi Eğitim Fakültesi Dergisi. 3(2), 5566.

Tokyo Gakugei University (2010). 2010 Study Guide, Tokyo Gakugei University, (in Japanese)

Tokyo metropolitan board of education, (2013). http://www.kyoiku.metro.tokyo.jp/press/ pr130613d.htm (in Japanese)

Ulubey,Ö ve Akçatepe,G. (2013). 1948 İlkokul Programı. Gözütok,D; B1kmaz,F.; Mızıkacı,F.; Alkın,Şahin, S,; Ulubey,Ö,; Koçer, E.; Türe,E. Ve Akçatepe,G. Cumhuriyetin İlanından 2013'e Öğretim Programlarının analizi. Hayat Bilgisi Örneği. Analysis of the teaching Programs from beginning the Republic to 2013: Life Science courses. (in Turkish) (pp.101-134).

Urano, H. (2011). An Approach for Improvement of Teacher's Competency of Lesson Management by the Workshop Type Inservice Training in Public Junior High School. Bulletin of the Center for Educational Research and Practice, Faculty of Education and Human Studies, Akita University, Vol.33, pp.111-121. (in Japanese)

Wang,A.H., Coleman, A. B., Coley,R.J. and Phelps,R.P. (2003). Preparing Teachers Around the World. Educational Testing Service. Policy information report. Retrieved from: https://www.ets.org/Media/Education_Topics/pdf/prepteach.pdf 
Yıldırım, A. (2011). Öğretmen Eğitiminde Çatışma Alanları ve Yeniden Yapılanma (Competing Agendas and Reform in Teacher Education). Uluslararası Eğitim Programları ve Öğretim Çalışmaları Dergisi, 1(1), 1-17.

Yıldız, K.(2004). Türkiye'de öğretmen yetiștirme. Teacher training in Turkey. (in Turkish). Karslı, M.D. (Ed.). Öğretmelik Mesleğine Giriş. (pp. 293-324). Ankara: PegemA .

YOK (2013). 2013 Pedagojik formasyon eğitimi sertifika programı tercih kılavuzu. http://www.osym.gov.tr/dosya/1-71403/h/2013--pedagojik-formasyon-tercih-kilavuzu--230120141.pdf. Pedagogical formation education certificate program: Guide (in Turkish).

\begin{tabular}{|l|l|}
\hline Hasan ŞEKER & Assoc. Prof. Dr. \\
& Department of Curriculum and Instruction, Education Faculty, \\
& Muğla Sitk1 Koçman University, Turkey \\
& E-mail: hseker@ mu.edu.tr \\
& \\
\hline \multirow{2}{*}{ Kenji MAEHARA } & Prof. Dr. \\
& Curriculum Center for Teachers, Tokyo Gakugei University, \\
& Tokyo, Japan \\
& E-mail: maehara@u-gakugei.ac.jp \\
\hline
\end{tabular}

